\title{
Carbon and Nitrogen Stable Isotope Ratios of Subtidal Benthic Invertebrates in an Estuarine Mangrove Ecosystem (Andhra Pradesh, India)
}

\author{
S. Bouillon ${ }^{a \star}$, A. V. $\operatorname{Raman}^{b}$, P. Dauby ${ }^{c}$ and F. Dehairs ${ }^{a}$ \\ ${ }^{a}$ Department of Analytical and Environmental Chemistry, Mangrove Management Group, Vrije Universiteit Brussel, \\ Pleinlaan 2, B-1050 Brussels, Belgium \\ ${ }^{\mathrm{b}}$ Department of Zoology, Marine Biological Laboratory, Andhra University, Visakhapatnam 530003, \\ Andhra Pradesh, India \\ ${ }^{\mathrm{c}}$ Laboratoire d'Oceanologie, Unité de Recherche en Biogeochimie des Isotopes Stables (URBIS), Université de Liège, \\ B6 Sart Tilman, B-4000 Liège, Belgium
}

Received 25 fanuary 2001 and accepted in revised form 28 fune 2001

\begin{abstract}
In order to assess the relative trophic importance of mangrove litterfall and aquatic primary production in the mangrove creeks of the Coringa Wildlife Sanctuary (Andhra Pradesh, India) and the adjacent semi-enclosed Kakinada Bay, carbon and nitrogen stable isotope ratios were determined in a variety of benthic invertebrate species collected at 22 sites during the pre-monsoon period (May-June) of 1997 and $1999 . \delta^{13} \mathrm{C}$ values showed little interspecific variation at any given location, but there was a distinct spatial gradient in consumer $\delta^{13} \mathrm{C}$ values of about $7 \%$, with more depleted values in the mangrove creeks $(-23 \cdot 6 \pm 0 \cdot 6 \%$ ), and gradually increasing in the mangrove outlets $(-21 \cdot 5 \pm 0 \cdot 9 \%$ o), a relatively restricted zone in the south-eastern part of Kakinada Bay adjacent to the mangroves $(-18 \cdot 8 \pm 0 \cdot 8 \%$, and the central and northern part of the Bay $(-16 \cdot 7 \pm 1 \cdot 4 \%$ ) which opens into the Bay of Bengal. This gradient is much larger than that observed during a previous study in suspended organic matter (maximum about $2 \cdot 7 \%$ ) and during this study in sediment organic matter (about $1 \cdot 5-2 \cdot 5 \%$ ). The observed carbon stable isotope ratios thus suggest a marked selectivity of the benthic invertebrate community for pelagic and benthic microalgal food sources and indicate that mangrove-derived and other terrestrial carbon is not a significant food source for benthic invertebrate communities in this ecosystem during the pre-monsoon period. Furthermore, $\delta^{13} \mathrm{C}$ values of sediment organic matter (SOM) suggest that terrestrial carbon is not a major contributor to the SOM-pool in this ecosystem. Evidence for seaward migration of Penaeid prawns was provided by some individuals caught in the North Bay which displayed low $\delta^{13} \mathrm{C}$ values of characteristic of fauna found in the mangrove creeks or outlets. Nitrogen stable isotope ratios were found to be a useful indicator of trophic level, even though there remained some overlap between $\delta^{15} \mathrm{~N}$ values of presumed low and higher trophic levels. Benthic invertebrates showed a $\delta^{15} \mathrm{~N}$ gradient of about $3 \cdot 2 \%$ between the mangrove creeks and the Central and North Bay whereas sediment $\delta^{15} \mathrm{~N}$ values showed a smaller spatial gradient of about $1 \cdot 6 \%$. This gradient which is hypothesized to reflect differences in inorganic nitrogen sources and availability.

(C) 2001 Elsevier Science Ltd. All rights reserved.
\end{abstract}

Keywords: mangroves; estuary; benthic invertebrates; carbon; nitrogen; stable isotopes; outwelling; sediment

\section{Introduction}

The degree of 'outwelling' of mangrove carbon to adjacent aquatic environments depends to a large degree on the geomorphology and tidal characteristics of the ecosystem (Lee, 1995, 1999a). If mangrovederived material is exported to the aquatic environment, either as dissolved or particulate organic carbon, the question arises whether it forms a substantial contribution in sustaining the pelagic and benthic foodwebs, and to what geographical extent (Robertson et al., 1992). The possibly limited importance of mangrove detritus in sustaining nearshore

^Corresponding author. E-mail: steven.bouillon@vub.ac.be communities has previously been suggested based on mass-balance restrictions (e.g. Li \& Lee, 1998). Wafar et al. (1997), for instance, compared the phytoplankton productivity in a western Indian mangrove estuary with the potential contribution of mangrove carbon, and concluded that mangrove production is mainly important for the microbial food web, but not for the particulate. Daniel and Robertson (1990) found a positive correlation between the amount of mangrove macrodetritus and epibenthos biomass and density in an Australian mangrove estuary, but stressed that different factors such as reduction of predation, increased food availability and increased living space, may explain this pattern. In contrast, Lee (1999b) 
found no positive effect of mangrove detritus enrichment on benthic faunal biomass and even found a decrease in species diversity.

Stable isotope analysis offers one of the possible approaches to study the incorporation of different carbon sources into foodwebs on the condition that there is a sufficiently large difference in the isotopic composition of the different primary carbon sources (terrestrial material, phytoplankton, benthic microalgae), and have been used to study benthic foodwebs in a variety of ecosystems (e.g. Dauby, 1990; Riera et al., 1999; Yoshii et al., 1999; Lepoint et al., 2000). Several stable isotope studies (e.g. Rodelli et al., 1984; Newell et al., 1995; Loneragan et al., 1997; Marguillier et al., 1997; Dehairs et al., 2000; Bouillon et al., 2000) have recently been carried out in mangrove ecosystems and have substantially increased the knowledge on mangrove foodwebs since the publication of the work of Odum and Heald (1975). The general conclusion resulting from many of these studies concerning the benthic communities in the aquatic environment adjacent to mangrove forests is that mangrove carbon is only used in a very restricted zone in and near mangrove forests but that its role is rapidly taken over by phytoplankton, even though mangrove detritus was present in suspended and sediment organic matter (Rodelli et al., 1984; Zieman et al., 1984; Fleming et al., 1990). One major drawback of the latter studies is that they based their conclusions on the distribution of $\delta^{13} \mathrm{C}$ values in invertebrates when compared to the $\delta^{13} \mathrm{C}$ of mangrove leaves and typical marine phytoplankton, but did not take into account the possibility of $\delta^{13} \mathrm{C}$-depleted phytoplankton in the mangrove creeks and nearmangrove aquatic environment (e.g. Dehairs et al., 2000; Bouillon et al., 2000) due to a ${ }^{13} \mathrm{C}$-depleted DIC-pool (dissolved inorganic carbon). This mechanism can even cause an overlap in the $\delta^{13} \mathrm{C}$ signal of these two sources and could make the interpretation of consumer stable isotope data difficult if not carefully considered.

In this study, carbon and nitrogen stable isotope ratios of subtidal benthic invertebrates and sediments were analysed at a wide variety of locations in an estuarine mangrove ecosystem in Andhra Pradesh (India) and baseline information of primary producer stable isotope ratios was used from previous studies in this area (Dehairs et al., 2000; Bouillon et al., 2000, 2001), in an effort to determine whether mangrove carbon was assimilated by benthic fauna in different zones of this ecosystem. In addition, whether the spatial trend in $\delta^{15} \mathrm{~N}$ values reported earlier (Dehairs et al., 2001) would be confirmed and could be related to sewage inputs (e.g. McKinney et al.,
1999; Risk \& Erdman, 2000), or to other processes was assessed.

\section{Study area}

The sampling sites (Figures 1 and 2) are located in the area between Kakinada Bay and the Gautami branch of the Godavari, the second largest river in India, and are located in the Southeastern state of Andhra Pradesh (between $82^{\circ} 15^{\prime}$ and $82^{\circ} 22^{\prime} \mathrm{E}, 16^{\circ} 43^{\prime}$ and $\left.17^{\circ} 00^{\prime} \mathrm{N}\right)$. The Godavari has a mean annual discharge of $11.1 \times 10^{14} 1$, of which $93-96 \%$ occurs during the wet monsoon season, and is listed as one of the largest POC (particulate organic carbon) transporting rivers in the world (Gupta et al., 1997). The Gautami Godavari opens into the Bay of Bengal, but has several branches into Kakinada Bay, the largest and most important being Coringa (total length of $26 \mathrm{~km}$ ) and Gaderu (total length of $11 \mathrm{~km}$ ). The area between the river and Bay is dominated by extensive mangrove forests and tidal mudflats. The shallow Kakinada Bay (depth ranging from 3 to $8 \mathrm{~m}$ at high tide) which covers approximately $150 \mathrm{~km}^{2}$, opens into the Bay of Bengal on its northern side, and is bordered along most of its eastern length by a narrow sand bar (Figure 1). Tides are semidiurnal, and tidal amplitude in the Bay is around 0.5 to $2 \mathrm{~m}$. Monsoon rainfall in the area usually occurs between July and September, and causes near-freshwater conditions in the southern part of the study area during this period. Estuarine conditions re-establish thereafter, and aquatic primary production increases towards the pre-monsoon period (April-June), during which turbidity reaches its lowest values in the entire region.

Benthic fauna in this area has witnessed a significant decrease in species diversity over the last 50 years, presumably due to the increased human pressure in Kakinada, a large city which currently hosts about 400000 inhabitants and is located on the western shore of Kakinada Bay. The Bay and creeks are important fishing areas and in addition, molluscs are harvested on a large scale for lime production.

\section{Materials and methods}

\section{Sample collection and preparation}

For benthic invertebrates, samples were taken along a linear transect from the mouth of Coringa Creek to the tip of Hope Island in the northern part of Kakinada Bay in June 1997 (open circles on Figure 1), and a variety of other sites were sampled in May-June 1999 (full circles). Sediment samples were taken 


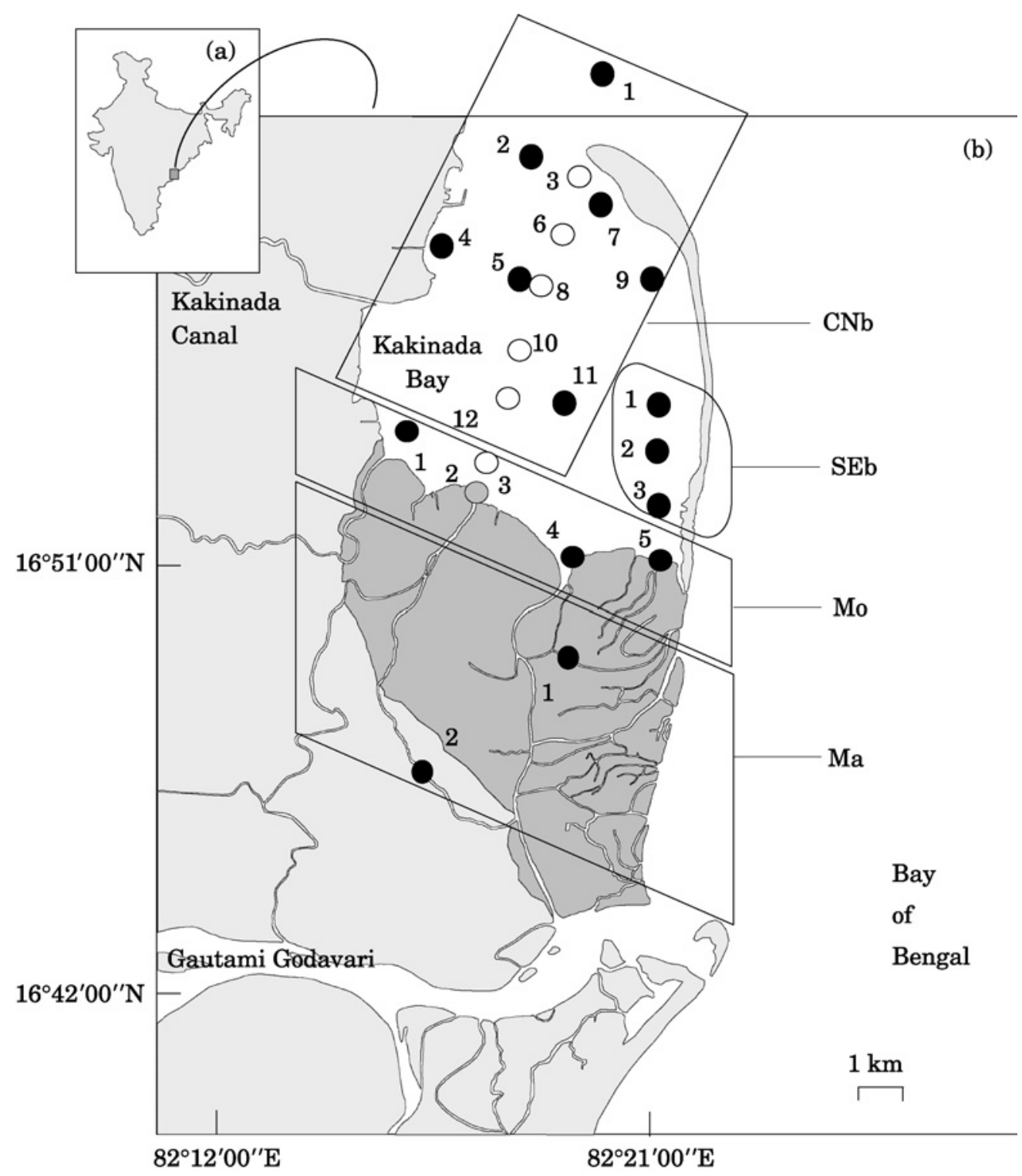

FIGURE 1. Location of the study area and sampling locations. Darkest areas represent the major mangrove-covered regions. Ma: mangrove creek stations, Mo: mangrove creek outlet stations, SEb: South-east Bay stations, CNb: Central and North Bay stations. Open circles indicate sampling locations of the June 1997 survey, black circles the May-June 1999 sampling location. Station Mo2 (in grey) was sampled during both surveys.

during surveys in July 1995 throughout the area (see Figure 2). Benthic fauna and sediments were collected using a dredge and Van Veen grab, and were kept in a cool box on board. After transportation to the field laboratory, all faunal samples were washed and dried at $60{ }^{\circ} \mathrm{C}$ for at least $24 \mathrm{~h}$. Samples were later ground to a fine powder, and subsamples for $\delta^{13} \mathrm{C}$ analysis were washed with dilute $\mathrm{HCl}$ to remove possible carbonates, and were redried. Subsamples for $\delta^{15} \mathrm{~N}$ analysis did not receive this treatment as this has been reported to affect $\delta^{15} \mathrm{~N}$ values (Goering et al., 1990; Bunn et al., 1995; Pinnegar \& Polunin, 1999).

\section{Measurement of stable isotope and elemental ratios}

Samples for stable isotope analysis were combusted in a Carlo Erba NA-1500 Elemental Analyser and the resulting gases $\left(\mathrm{CO}_{2}\right.$ and $\left.\mathrm{N}_{2}\right)$ were cryogenically separated in a manual extraction line. Stable isotope ratios were then determined on a Delta $\mathrm{E}$ Finnigan Mat isotope ratio mass spectrometer and are expressed relative to the conventional standards, i.e. PDB limestone for carbon (Coplen, 1996) and atmospheric $\mathrm{N}_{2}$ for nitrogen (Mariotti, 1983) as $\delta$ values, defined as: 

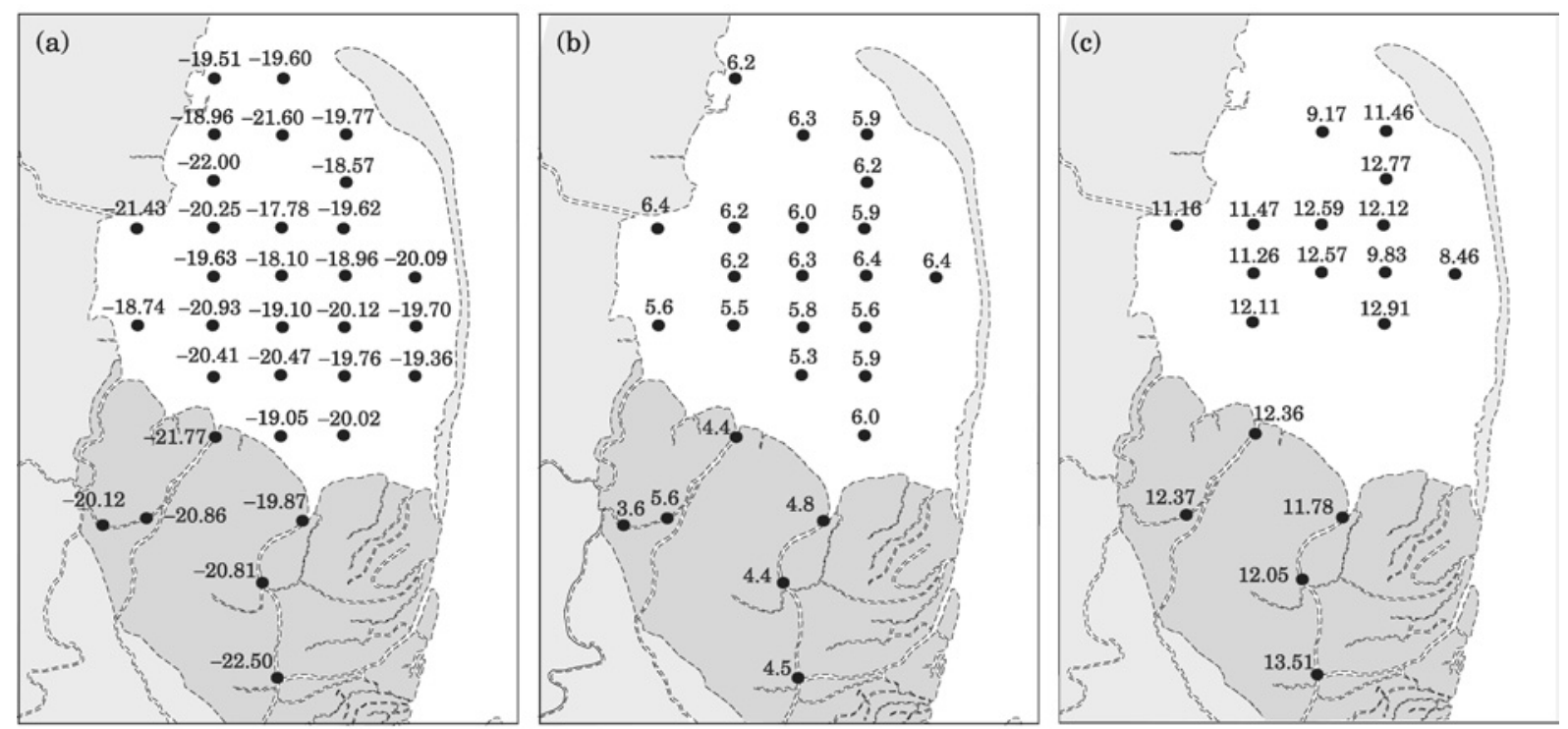

FIgURE 2. Spatial distribution of (a) $\delta^{13} \mathrm{C}$ values, (b) $\delta^{15} \mathrm{~N}$ values, and (c) elemental ratios in the Coringa-Kakinada estuarine ecosystem.

TABLE 1. Average $\delta^{13} \mathrm{C}$ values (expressed in \%o) of all invertebrates sampled at each of the sampling locations. Also indicated are the standard deviation on the mean $\delta^{13} \mathrm{C}$, the number of samples, and the minimum and maximum $\delta^{13} \mathrm{C}$ at each location

\begin{tabular}{|c|c|c|c|}
\hline Location & Average $\delta^{13} \mathrm{C}$ & Minimum $\delta^{13} \mathrm{C}$ & Maximum $\delta^{13} \mathrm{C}$ \\
\hline Ma1 & $-23 \cdot 6 \pm 0 \cdot 2(3)$ & $-23 \cdot 8$ & $-23 \cdot 3$ \\
\hline Ma2 & $-23 \cdot 6 \pm 0 \cdot 7$ & $-24 \cdot 7$ & $-22 \cdot 4$ \\
\hline Mo1 & $-21.8 \pm 0.9(8)$ & $-23 \cdot 1$ & $-20 \cdot 5$ \\
\hline Mo2 & $-21 \cdot 5 \pm 1 \cdot 0(10)$ & $-23 \cdot 0$ & $-19 \cdot 9$ \\
\hline Mo3 & $-21 \cdot 1 \pm 0 \cdot 9$ & $-21 \cdot 6$ & $-20 \cdot 0$ \\
\hline Mo4 & $-21 \cdot 5 \pm 0 \cdot 8(14)$ & $-22 \cdot 5$ & $-19 \cdot 7$ \\
\hline Mo5 & $-20 \cdot 5 ;-20 \cdot 2$ & - & - \\
\hline SEb1 & $-18 \cdot 4 \pm 0 \cdot 7(8)$ & $-19 \cdot 6$ & $-17 \cdot 8$ \\
\hline $\mathrm{SEb} 2$ & $-18 \cdot 6 \pm 1 \cdot 0(10)$ & $-20 \cdot 2$ & $-16 \cdot 2$ \\
\hline SEb3 & $-19 \cdot 0 \pm 0 \cdot 6(10)$ & $-20 \cdot 1$ & $-18 \cdot 0$ \\
\hline $\mathrm{CNb}^{\star}{ }^{\star}$ & $-17 \cdot 1 \pm 0 \cdot 9(10)$ & $-18 \cdot 7$ & $-15 \cdot 9$ \\
\hline $\mathrm{CNb} 2$ & $-16 \cdot 3 \pm 1 \cdot 9(7)$ & $-17 \cdot 9$ & $-13 \cdot 2$ \\
\hline $\mathrm{CNb} 3$ & $-16 \cdot 5 \pm 1 \cdot 0(4)$ & $-17 \cdot 3$ & $-15 \cdot 3$ \\
\hline $\mathrm{CNb} 4$ & $-16 \cdot 2 \pm 0 \cdot 5(10)$ & $-17 \cdot 3$ & $-15 \cdot 7$ \\
\hline CNb5 & $-16 \cdot 3 \pm 1 \cdot 2(14)$ & $-18 \cdot 0$ & $-14 \cdot 4$ \\
\hline CNb6 & $-16 \cdot 4 \pm 0.6(4)$ & $-17 \cdot 0$ & $-15 \cdot 6$ \\
\hline $\mathrm{CNb} 7^{\star}$ & $-15 \cdot 1(1)$ & - & - \\
\hline CNb8 & $-16 \cdot 7 \pm 1 \cdot 0(7)$ & $-18 \cdot 2$ & $-15 \cdot 4$ \\
\hline CNb9 & $-18 \cdot 4 ;-17 \cdot 7$ & - & - \\
\hline CNb10 & $-16 \cdot 6 \pm 1 \cdot 2(7)$ & $-18 \cdot 9$ & $-15 \cdot 1$ \\
\hline $\mathrm{CNb} 11$ & $-15 \cdot 9 \pm 1 \cdot 2(5)$ & $-16 \cdot 9$ & $-13 \cdot 8$ \\
\hline $\mathrm{CNb} 12$ & $-17 \cdot 1 \pm 1 \cdot 5(7)$ & $-19 \cdot 2$ & $-14 \cdot 9$ \\
\hline
\end{tabular}

${ }^{\star}$ One low $\delta^{13} \mathrm{C}$ value measured for a Penaeid prawn was excluded (see discussion).

$$
\delta \mathrm{R}=\left[\left(\mathrm{X}_{\text {sample }}-\mathrm{X}_{\text {standard }}\right) / \mathrm{X}_{\text {standard }}\right] \times 10^{3}[\% \mathrm{o}]
$$

where $\mathrm{R}={ }^{13} \mathrm{C}$ or ${ }^{15} \mathrm{~N}$, and $\mathrm{X}={ }^{13} \mathrm{C} /{ }^{12} \mathrm{C}$ or ${ }^{15} \mathrm{~N} /{ }^{14} \mathrm{~N}$. The normal working standard for carbon was $\mathrm{CO}_{2}$ produced from Carrara marble, and high-purity tank
$\mathrm{N}_{2}$ was used as the working standard for nitrogen. Internal reference materials used were ammonium sulphate (IAEA-N1, IAEA-N2) and ammonium nitrate (IAEA-NO3) for $\delta^{15} \mathrm{~N}$, and sucrose (IAEA-C6) and polyethylene (IAEA-CH-7) for $\delta^{13} \mathrm{C}$. Standard 

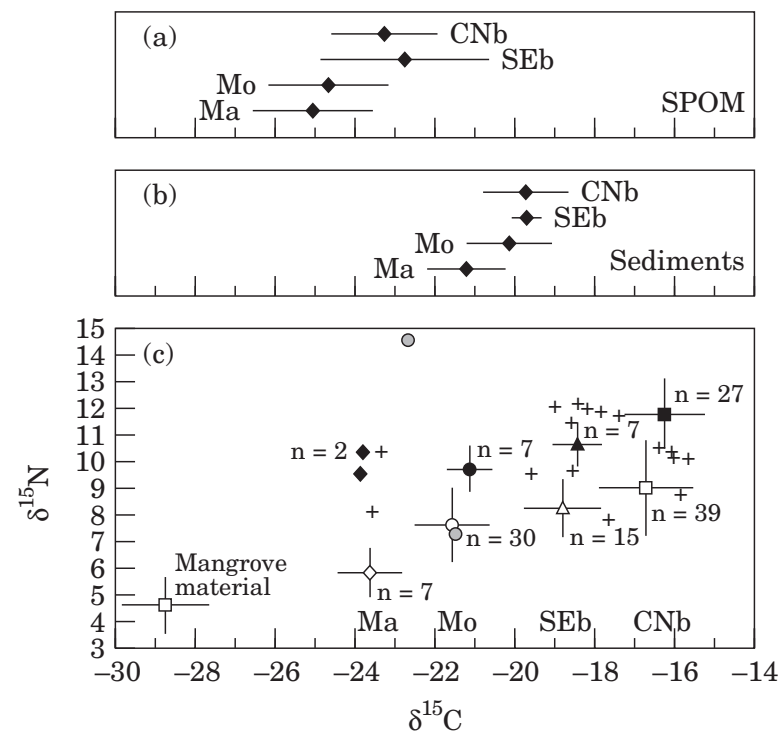

Figure 3. Average $\delta^{13} \mathrm{C}$ of (a) suspended particulate organic matter (SPOM, data from Bouillon et al., 2000) and (b) sediment organic matter, and (c) $\delta^{13} \mathrm{C}-\delta^{15} \mathrm{~N}$ plot for mangrove litter and benthic invertebrates collected in the mangrove creeks (Ma), mangrove outlets (Mo), South-east Bay (SEb), and Central and North Bay (CNb). Open symbols refer to species presumed to occupy a low trophic level, black symbols refer to species of higher trophic levels, and ' + ' indicate species of unknown trophic level from all zones. Two penaeid prawns collected in the North Bay with distinctly low $\delta^{13} \mathrm{C}$ values (see discussion) are shown as grey circles. Data on mangrove litter are from Bouillon et al. (2001). Error bars indicate 1 SD.

deviations on ten aliquots of the same sample were lower than $0 \cdot 2 \%$ for both $\delta^{13} \mathrm{C}$ and $\delta^{15} \mathrm{~N}$. Nitrogen stable isotope ratios of sediments were determined with a continuous-flow IRMS system (Micromass Optima coupled to a Carlo Erba CNS Analyser) with an analytical precision of $\pm 0 \cdot 2 \%$ for $\delta^{15} \mathrm{~N}$. Elemental $(\mathrm{C}, \mathrm{N})$ analysis of sediment organic matter was performed by combusting pre-weighed and HCl-treated sediment samples in a Carlo Erba NA-1500 Elemental Analyser, similar to the method described by Nieuwenhuize et al. (1994).

\section{Results}

\section{Sediments}

Sediment organic matter had $\delta^{13} \mathrm{C}$ values between $-24 \cdot 2$ and $-17 \cdot 8 \%$, with overall averages of $-21 \cdot 3 \pm 1 \cdot 0 \%$ ( $n=5$, mangrove creeks), $-20 \cdot 2 \pm$ $1 \cdot 1 \%$ o ( $\mathrm{n}=4$, mangrove outlets), $-19 \cdot 7 \pm 0 \cdot 4 \%$ $(n=3$, South-east Bay) and $-19 \cdot 7 \pm 1 \cdot 2 \%$ o $(n=19$, Central and North Bay) [Figure 2(a)]. In the Bay,
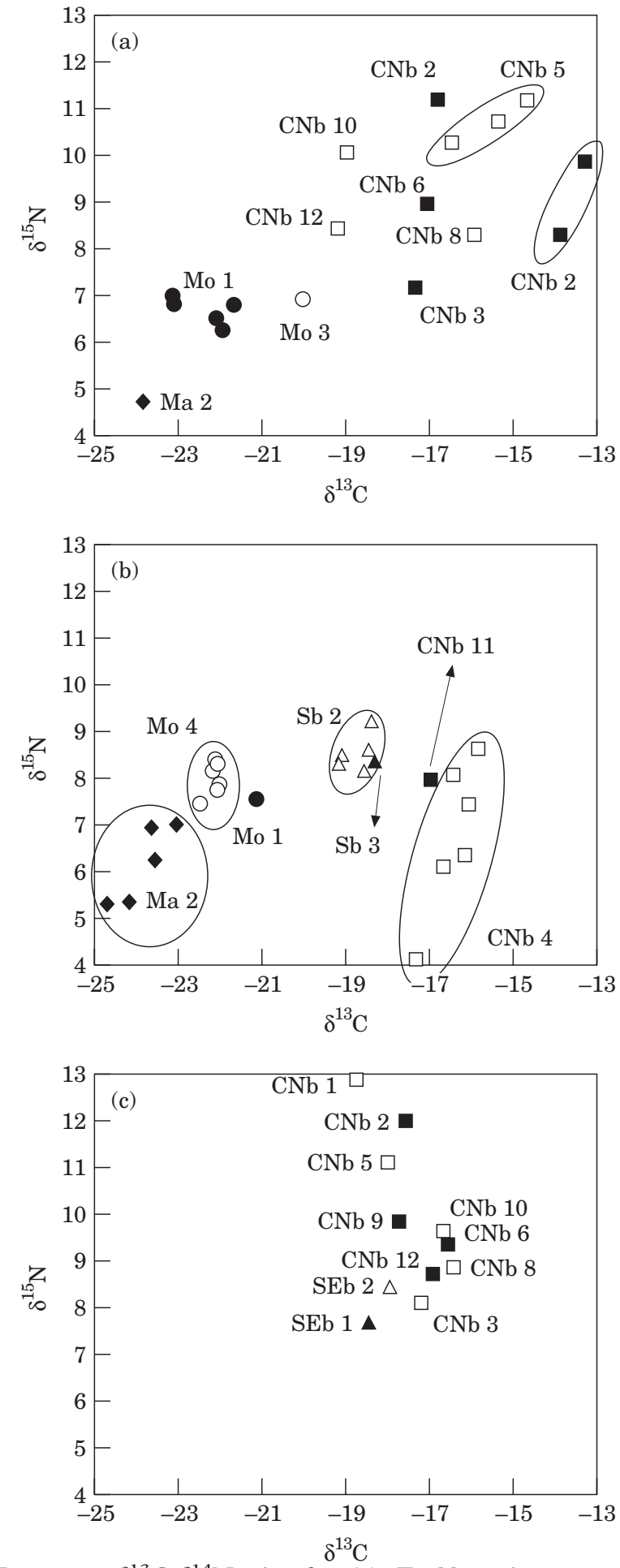

Figure 4. $\delta^{13} \mathrm{C}-\delta^{14} \mathrm{~N}$ plot for (a) Typhlocarcinus sp., (b) Tellina spp., and (c) Paphia undulata sampled at different locations throughout the study area (see Figure 1 for location of stations).

however, the three most depleted values (all $<-21 \%$ ) were observed near the outfall of Kakinada Canal draining the sewage systems of Kakinada town, 
and in a northeastern direction from that point [Figure $2(\mathrm{a})] . \delta^{15} \mathrm{~N}$ values of sediments [Figure 2(b)] also showed a spatial gradient, with relatively low values in the mangrove creeks $(+4 \cdot 4 \pm 0 \cdot 8 \%, \mathrm{n}=4)$, but higher values in the mangrove outlets $(+5 \cdot 1 \pm 0 \cdot 8 \%, \mathrm{n}=3)$, South-east Bay $(+6 \cdot 4 \%, \mathrm{n}=1)$ and the rest of the Bay $(+6 \cdot 0 \pm 0 \cdot 3 \%, n=16)$. Organic carbon content of all samples was relatively low $(0 \cdot 40-1 \cdot 42 \%$ dry weight), and $\mathrm{C} / \mathrm{N}$ ratios varied between 8.5 and 13.5 with no apparent differences between regions, although some Bay stations showed remarkably low values $(8 \cdot 5,9 \cdot 2$, 9.8) compared to other Bay stations [average $12 \cdot 0 \pm 0 \cdot 7, \mathrm{n}=10$, Figure 2(c)].

\section{Benthic invertebrates}

Overall, $\delta^{13} \mathrm{C}$ values of benthic invertebrates (see Appendix I) ranged between $-24 \cdot 7 \%$ (for an individual of the bivalve Tellina sp. 1 at $\mathrm{Ma} 2$ ) and $-13 \cdot 2 \%$ (for an individual of the crab Typhlocarcinus sp. at $\mathrm{CNb} 2$ ), while $\delta^{15} \mathrm{~N}$ values ranged from $+4 \cdot 1 \%$ o (for Tellina sp. 2 at $\mathrm{CNb} 4$ ) to $+14.5 \%$ o (for a Metapenaeus monoceras at $\mathrm{CNb} 1$ ).

Stable carbon isotope ratios for different species sampled at a particular location were usually quite consistent and, with only three exceptions, showed a range of less than $4 \%$. Thus, average $\delta^{13} \mathrm{C}$ values of all invertebrates at a given location were calculated and were found to be similar in spatially adjacent locations, allowing us to distinguish different zones on the basis of invertebrate $\delta^{13} \mathrm{C}$ values (Table 1). Stations were thus characterized as Mangrove creek locations (Ma, average $\delta^{13} \mathrm{C}$ values around $-23 \cdot 5 \%$ ), Mangrove outlets (Mo, average $\delta^{13} \mathrm{C}$ values around $-21 \cdot 5 \%$ ), South-east Bay stations ( $\mathrm{SEb}$, average $\delta^{13} \mathrm{C}$ values around $-18 \cdot 5 \%$ ), and Central and North Bay stations $\left(\mathrm{CNb}\right.$, average $\delta^{13} \mathrm{C}$ values around $-16 \cdot 5 \%$ ). Stations for which only one or two data were available (i.e. $\mathrm{Mo} 5, \mathrm{CNb} 7, \mathrm{CNb} 9$ ) were included in the group most adjacent to them geographically. In general, there appears to be a shift in benthic invertebrate $\delta^{13} \mathrm{C}$ values of about $7 \%$ o between the mangrove creeks and the North \& Central Bay regions [Figure 3(c)]. Two Penaeid prawns caught in the North Bay, however, were very depleted in ${ }^{13} \mathrm{C}$ $\left[\delta^{13} \mathrm{C}=-22 \cdot 7\right.$ and $-21.5 \%$, see Figure $\left.3(\mathrm{c})\right]$ relative to other invertebrates from this zone, and their carbon isotopic signature was similar to that of organisms found in the mangrove creeks or outlets. Their $\delta^{13} \mathrm{C}$ data were consequently not used in calculations of station-averaged $\delta^{13} \mathrm{C}$ values (see above).

Species were classified as ' low' or ' higher' trophic level species when data on their trophic status were available. Thus, all bivalves, the gastropod Cerithidea cingulata, the brachiopod Lingula sp., and the depositfeeding crabs Dorippe facchino, Macrophthalmus sp., and Typhlocarcinus sp. were initially grouped as low trophic level species, and all penaeid prawns, the predatory or scavenging gastropods Babylonia spirata, Volema cochlidium, Murex trapa, Thais lacera and Nassarius spp., the crabs Leucosia sp., Charybdis sp., Portunus sanguinolentus, and Phylira sp., and the polychaete Diopatra neapolitana were considered to occupy higher trophic levels. The bivalves Meretrix meretrix and Pinctada radiata, however, were then re-classified as ' unknown' trophic level species based on their intermediate $\delta^{15} \mathrm{~N}$ values (see discussion). All other species were considered to occupy an unknown trophic level. According to this classification, it appeared that higher trophic levels showed, on average, higher $\delta^{15} \mathrm{~N}$ values (by $2 \cdot 1$ to $3 \cdot 8 \%$ ), and that there was also a marked spatial $\delta^{15} \mathrm{~N}$ gradient between the mangrove creeks and the Central and North Bay of about $3.2 \%$ which could be observed in both low and high trophic levels [Figure 3(c)].

\section{Discussion}

\section{Sediments}

Sediment organic matter showed a shift in $\delta^{13} \mathrm{C}$ values between the mangrove creeks $(-21 \cdot 3 \%$ ) and the South-east and North Bay, where a zone of maximum $\delta^{13} \mathrm{C}$ values between $-17 \cdot 8$ and $-19 \cdot 1 \%$ can be found in the centre of the Bay [Figure 2(a)]. In the Bay, most depleted values $(<-21 \%$ ) can be found in the region where satellite data indicate the plume of the Kakinada Canal, and are thus thought to be a reflection of larger inputs of ${ }^{13} \mathrm{C}$-depleted terrestrial or sewage material. The magnitude of the overall $\delta^{13} \mathrm{C}$ gradient is only slightly smaller than that found in suspended organic matter, but suspended matter was found to be on average about $3-4 \%$ more ${ }^{13} \mathrm{C}$ depleted than sediment organic matter (Bouillon et al., 2000) [Figure 3(a-c)]. Such a discrepancy between suspended matter and sediment $\delta^{13} \mathrm{C}$ values has also been found by Middelburg et al. (1998) in the Scheldt Estuary, with sediment $\delta^{13} \mathrm{C}$ being enriched relative to the suspended matter in the upper estuary, but depleted in the lower estuary. $\mathrm{C} / \mathrm{N}$ ratios of sediments in this study [Figure 2(c)] are also higher than the average values found in suspended matter (between 8.5 and 10, see Dehairs et al., 2000). These results indicate first of all that mangrove-derived carbon (with an average $\delta^{13} \mathrm{C}$ of $-28 \cdot 7 \%$, Bouillon et al., 2001) and other terrestrial carbon sources ( - 26.5\%o, e.g. Hellings et al., 1999), do not appear to contribute substantially to the sediment organic 
matter pool of the mangrove creeks and adjacent Bay. Furthermore, the discrepancy in $\mathrm{C} / \mathrm{N}$ ratios and $\delta^{13} \mathrm{C}$ values between suspended and sediment organic matter indicate different relative contributions of carbon sources in these two pools. However, while the higher $\mathrm{C} / \mathrm{N}$ ratios in sediments would suggest a larger contribution by terrestrial sources, the higher $\delta^{13} \mathrm{C}$ values in SOM indicate the opposite. A marked spatial shift of about $1.6 \%$ can also be observed in the sedimentary $\delta^{15} \mathrm{~N}$ record [Figure 2(b)], and will be discussed in conjunction with the parallel shift in consumer $\delta^{15} \mathrm{~N}$ values below.

\section{$\delta^{13} C$ values of benthic invertebrates: importance of different primary producers}

The overall distribution of $\delta^{13} \mathrm{C}$ values for benthic invertebrates collected in this survey [Table 1, Appendix I and Figure 3(c)] shows that, considering a trophic enrichment of $\sim 1 \%$, benthic invertebrates in the South-eastern, Central and Northern part of Kakindada Bay did not rely substantially on mangrove ( $-28 \cdot 7 \%$, Bouillon et al., 2001) or other terrestrial carbon sources $(\sim-26 \cdot 5 \%$, e.g. Hellings et al., 1999) during the study period. In fact, the $\delta^{13} \mathrm{C}$ values of benthic invertebrates in these areas are typical for a marine, phytoplankton-based benthic food web, and some of the more ${ }^{13} \mathrm{C}$-enriched values $(>-15 \%$ ) also suggest some input of ${ }^{13} \mathrm{C}$-enriched carbon sources, such as benthic microalgae (France, 1995). We have no direct measurements of the isotopic signature of these algae from the Bay or Creek bottoms due to the practical difficulties in sampling them in this environment, but benthic microalgae from the intertidal mangrove flats in this area have been found to have an isotopic signature of around $-17 \cdot 3 \%\left(\delta^{13} \mathrm{C}\right)$ and between +0.5 and $+4.5 \%\left(\delta^{15} \mathrm{~N}\right)$ (Bouillon et al., 2001), whereas SPOM from the adjacent waters during the pre-monsoon period typically has $\delta^{13} \mathrm{C}$ values of -23 to $-20 \%$ (Bouillon et al., 2000). Benthic microalgae have been found to occur throughout the study area (C. Kalavati, unpublished data), despite the high turbidity levels which may be encountered.

More depleted values were found in the mangrove outlets $(-21.5 \pm 0.9 \%, \mathrm{n}=37)$ and creeks $(-23 \cdot 6 \pm 0 \cdot 6 \%, n=11)$. However, phytoplankton $\delta^{13} \mathrm{C}$ values in this dynamic ecosystem have been suggested to be spatially and seasonally variable (Dehairs et al., 2000; Bouillon et al., 2000; Bouillon \& Dehairs, 2000) and are thought to exhibit a $\delta^{13} \mathrm{C}$ gradient between the mangrove creeks (depleted values) and the North Bay (enriched values). The magnitude of the $\delta^{13} \mathrm{C}$ gradient observed in benthic invertebrates $(\sim 7 \%)$ is much larger than that ob- served in suspended organic matter $(\sim 2.5 \%)$ or sediment organic matter $(\sim 1.5 \%)$ but is quite similar to the average difference in zooplankton $\delta^{13} \mathrm{C}$ between the mouth of Coringa (see Figure 1) and the North Bay ( $6 \%$, Bouillon et al., 2000). Benthic invertebrates in the mangrove creeks and outlets were observed to be more ${ }^{13} \mathrm{C}$-depleted relative to the sediment organic matter, whereas those in the South-east, Central and North Bay were enriched relative to the sediment organic carbon pool. In contrast, compared to the average $\delta^{13} \mathrm{C}$ values for suspended organic matter (Bouillon et al., 2000), benthic invertebrates were enriched at all locations, although markedly more so in the Bay environment than in the mangrove creeks [Figure $3(\mathrm{a}-\mathrm{c})$ ].

The magnitude of the observed $\delta^{13} \mathrm{C}$ gradient in benthic invertebrates and a comparison with $\delta^{13} \mathrm{C}$ data of suspended and sediment organic matter thus indicate a marked selectivity for pelagic and benthic microalgal carbon sources. Phytoplankton and benthic microalgae are expected to exhibit a larger $\delta^{13} \mathrm{C}$ gradient because of a more ${ }^{13} \mathrm{C}$-depleted DIC-pool (dissolved inorganic carbon) in and near the mangrove creeks, where bacterial respiration of ${ }^{13} \mathrm{C}$ depleted vascular plant material will result in a dilution of the DIC-pool with isotopically light $\mathrm{CO}_{2}$ (e.g. Marguillier et al., 1997; Bouillon et al., 2000; S. Bouillon, unpublished data). It is also conceivable that there are spatial differences in the importance of carbon sources, i.e. mangrove carbon (and other terrestrial sources) could be more important in the mangrove creeks yet be fully replaced by algal sources towards the marine end, in which case we would also expect to find a gradient of increasing $\delta^{13} \mathrm{C}$ values towards the northern Bay. However, the discrepancy between benthic invertebrate $\delta^{13} \mathrm{C}$ values and the mangrove $\delta^{13} \mathrm{C}$ signature [Figure 3(c)] and the fact that phytoplankton $\delta^{13} \mathrm{C}$ values are expected to be more ${ }^{13} \mathrm{C}$-depleted in the mangrove creeks relative to marine phytoplankton and thus presumably overlap with the $\delta^{13} \mathrm{C}$ values observed in benthic invertebrates, suggest that this is not the case. A similar steeper gradient in clam $\delta^{13} \mathrm{C}$ values compared to suspended matter $\delta^{13} \mathrm{C}$ was found by Canuel et al. (1995) in San Francisco Bay, and was also interpreted as selectivity for phytoplanktonic sources. It thus appears that during the pre-monsoon period, when turbidity is least and the numerical abundance of phytoplankton is at a maximum, pelagic and benthic microalgal sources are the dominant primary producers sustaining the benthic community in this ecosystem. Whether this situation is representative of other seasons remains to be determined. 
When comparing $\delta^{13} \mathrm{C}$ data from the Central and North Bay and the mangrove regions, it appears that the two $\delta^{13} \mathrm{C}$ distributions are entirely non-overlapping, except for two rather negative values $(-21.5$ and $-22 \cdot 7 \%$ ) found in the North Bay [Figure 3(c), shown as grey-filled circles]. These two negative values were found in 2 species of penaeid prawns (Penaeus merguiensis and Metapenaeus monoceros, respectively), i.e. mobile species which are expected to migrate during this season from the mangrove creeks towards the marine environment. Thus, as the tissues of these organisms require some time to equilibrate with the isotopically distinct new diet (Riera et al., 2000), these low values are hypothesized to indicate that these individuals had only recently migrated from the mangrove regions (e.g. Macrobrachium rosenbergii collected at Coringa mouth was found to have a $\delta^{13} \mathrm{C}$ of about $-21 \%$ ) to the North Bay, whereas some other Penaeids captured in the North Bay (including other individuals of the same species) had 'normal' values of -15 to $-17 \%$. The use of carbon stable isotopes as a tracer of shrimp migration has been reported earlier (e.g. Fry, 1983; Riera et al., 2000). The $\delta^{15} \mathrm{~N}$ values of these two specimens were among the highest and lowest recorded in this study [Figure 3(c), Appendix I]. Large variations in penaeid $\delta^{15} \mathrm{~N}$ values have been reported earlier (Riera et al., 2000), and we currently do not have a convincing explanation for this.

Finally, some common species were sampled at different sites, and examples of the spatial variability in their stable isotopic signatures are given in Figure 4. These data show three quite different patterns and thus indicate that species-specific differences in relative contributions of carbon sources also occur. For Typhlocarcinus sp. [Figure 4(a)], the general trend of Figure $3(\mathrm{c})$ is confirmed, i.e. an enrichment in ${ }^{13} \mathrm{C}$ and ${ }^{15} \mathrm{~N}$ is found when going from the mangrove creeks to the Central and North Bay but in addition, the Central and North Bay data also display some variability, suggesting that Typhlocarcinus sp. feeds in a highly selective way. For Tellina spp. [Figure 4(b)], the $\delta^{13} \mathrm{C}$ trend is also confirmed, but the specimens from station $\mathrm{CNb} 4$, near the outfall of Kakinada Canal, are depleted in ${ }^{15} \mathrm{~N}$ relative to the expected pattern. For Paphia undulata [Figure 4(c)], no data are available for $\mathrm{Ma}$ or Mo stations, but it can be seen that within the Central and North Bay, substantial differences in $\delta^{15} \mathrm{~N}$ values are observed whereas $\delta^{13} \mathrm{C}$ values of $\mathrm{SEb}$ and $\mathrm{CNb}$ stations are relatively uniform, suggesting less selective feeding.

$\delta^{15} N$ values of sediments and benthic invertebrates When species in each zone were grouped according to their assumed or known trophic status (with a distinc- tion made between ' low' or ' higher' trophic levels), it appeared that higher trophic levels showed on average higher $\delta^{15} \mathrm{~N}$ values (by $2 \cdot 1$ to $3 \cdot 8 \%$ ), and that there was also a marked spatial $\delta^{15} \mathrm{~N}$ gradient between the mangrove creeks and the Central and North Bay of about $3 \cdot 2 \%$ which could be observed in both low and higher trophic levels [Figure 3(c)]. By comparing the $\delta^{15} \mathrm{~N}$ values of species of unknown trophic status with the average $\delta^{15} \mathrm{~N}$ values of species of known low or high trophic level from that zone, we can tentatively classify Oratosquilla sp. and Harpiosquilla sp. as ' higher' trophic level species, whereas Meretrix meretrix and Acaudina molpaidoides had intermediate $\delta^{15} \mathrm{~N}$ values. For Meretrix meretrix this is confirmed by gut content analysis which indicated the presence of animal tissues (C. Kalavati, unpublished data). For the bivalve Pinctada radiata and the sponge Tetilla dactyoloidea, however, insufficient data are available to assess its trophic status. Overall, the $\delta^{15} \mathrm{~N}$ signature appears to be a useful indicator of trophic level, if the local baseline $\delta^{15} \mathrm{~N}$ values are taken into account. However, in each of the zones, there remained some overlap in the $\delta^{15} \mathrm{~N}$ signatures of the two proposed trophic levels. The degree of ${ }^{15} \mathrm{~N}$-enrichment between two trophic levels and the mechanisms causing it are still not yet fully understood (Ponsard \& Averbuch, 1999) and the enrichment factor has been found to be quite variable (e.g. Adams \& Sterner, 2000), but is assumed to be on average about $2 \cdot 6$ to $3 \cdot 4 \%$ o (Owens, 1987; Minagawa \& Wada, 1984).

The spatial $\delta^{15} \mathrm{~N}$ gradient could also be noticed in the sediment organic matter [Figure 2(b)], but was less pronounced with a difference of about $1 \cdot 6 \%$ between the mangrove creeks and the Central and North Bay. Contrary to our expectations, the distribution of sedimentary $\delta^{15} \mathrm{~N}$ values was relatively uniform throughout the Bay and was not indicative of major sewage impact from the Kakinada Canal [Figure 2(c)]. Such a $\delta^{15} \mathrm{~N}$ gradient was also noted in this area in zooplankton (Bouillon et al., 2000) and fish (S. Bouillon, unpublished data). Thus, whereas low trophic level species in the mangrove creeks had $\delta^{15} \mathrm{~N}$ values about $1.5 \%$ o higher than sediment organic matter, this difference increased to almost 3\% in the Central and North Bay. Several factors may be responsible for this $\delta^{15} \mathrm{~N}$ trend, which is ultimately related to $\delta^{15} \mathrm{~N}$ differences in primary producers. First, the source nitrogen for the primary producers in the different regions may have a variable $\delta^{15} \mathrm{~N}$ signal. For example, $\mathrm{NO}_{3}^{-}$from sewage waste has been found to have significantly higher $\delta^{15} \mathrm{~N}$ values than other $\mathrm{NO}_{3}^{-}$sources (Heaton, 1986; Macko \& Ostrom, 1994), and thus ecosystem $\delta^{15} \mathrm{~N}$ has been found to increase with the degree of urbanization of 
the watershed (e.g. Fry, 1999; McClelland et al., 1997; McClelland \& Valiela, 1998). Risk and Erdmann (2000) found higher $\delta^{15} \mathrm{~N}$ values in invertebrates in sewage-impacted coral reef invertebrates than in non-impacted reef invertebrates. On the other hand, sewage effluent organic matter has been found to have low $\delta^{15} \mathrm{~N}$ values (e.g. Sweeney \& Kaplan, 1980; Macko \& Ostrom, 1994) causing invertebrates to exhibit lower $\delta^{15} \mathrm{~N}$ values in the vicinity of sewage outfalls than in nearby unpolluted marine locations (e.g. Rogers, 1999; Thornton \& McManus, 1994; Tucker et al., 1999). Several bivalves collected near to the outfall of Kakinada Canal (station $\mathrm{CNb} 4$ ) did show relatively low $\delta^{15} \mathrm{~N}$ values compared to other low trophic level species in the Bay [Figure 4(b), Appendix I), but their high $\delta^{13} \mathrm{C}$ values $(\sim-17 \%$ ) are not indicative of direct utilization of sewagederived matter.

Secondly, the load and the phytoplankton demand for these nutrients $\left(\mathrm{NO}_{3}^{-}\right.$and $\left.\mathrm{NH}_{4}^{+}\right)$is an important factor controlling primary producer $\delta^{15} \mathrm{~N}$ values. It has been shown that $\delta^{15} \mathrm{~N}$ values of particulate (and sediment) organic matter increase as $\mathrm{NO}_{3}^{-}$concentrations decrease, either along a spatial gradient or during the course of a phytoplankton bloom, and this is due to the selective assimilation of ${ }^{14} \mathrm{NO}_{3}^{-}$resulting in an isotopically heavier DIN pool and subsequently newly produced biomass (see Altabet \& Francois, 1994 and references therein), and a similar situation holds for $\mathrm{NH}_{4}^{+}$assimilation (Cifuentes et al., 1988). Thus, spatial and seasonal variations in the DIN concentration and speciation will affect primary producer $\delta^{15} \mathrm{~N}$ values and these will in turn be reflected in consumer tissue isotopic composition. Another process which has been shown to increase $\delta^{15} \mathrm{~N}$ values locally or seasonally is denitrification, which causes an enrichment in the residual DIN pool, and subsequently in all ecosystem compartments (e.g. Mariotti et al., 1984).

In the study area, ammonium concentrations (AV Raman, unpublished data) have been found to be highest (average values of $0.6,1.3,8.9$ and $13.1 \mu \mathrm{M}$ for the North Bay, South Bay, Gaderu and Coringa, respectively) during the monsoon period (JulySeptember), and afterwards decrease until values of $<0 \cdot 1 \mu \mathrm{M}$ are reached by the end of the pre-monsoon period (i.e. the sampling period). Thus, it appears that $\mathrm{NH}_{4}^{+}$consumption depletes the $\mathrm{NH}_{4}^{+}$pool and this should lead to an enrichment of the remaining pool in ${ }^{15} \mathrm{~N}$. In a similar way, there is a spatial gradient with $\mathrm{NH}_{4}^{+}$generally being a more important constituent of the DIN pool in the mangrove creeks and outlets, and nitrate taking over this role in the Bay waters. As Cifuentes et al. (1988) mention that no $\mathrm{NO}_{3}^{-}$uptake by phytoplankton takes place as long as the $\mathrm{NH}_{4}^{+}$ concentration remains $>2 \mu \mathrm{M}$, for the present study this would imply that $\mathrm{NO}_{3}^{-}$uptake only occurs towards the end of the pre-monsoon period, for the whole area. We thus hypothesize that uptake by DIN, imported via the mangrove creeks and other freshwater sources, enriches the remaining DIN pool in the Bay and results in the observed $\delta^{15} \mathrm{~N}$ gradient in sediments and consumers.

\section{Concluding remarks}

Overall, our results indicate a strong selectivity of the benthic invertebrate community for local algal sources and a limited trophic dependancy on mangrove or other terrestrial carbon sources. In contrast to the wide range of rescources used by intertidal invertebrates (Bouillon et al., 2001), benthic fauna in the subtidal regions appear to show much less diversity in their carbon sources, as evidenced by the relative uniformity of $\delta^{13} \mathrm{C}$ values at each location. The stable isotopic composition of sediments furthermore suggest that burial of mangrove and terrestrial carbon in sediments is limited in this particular system. Besides the evidence provided by stable isotopes (e.g. Newell et al., 1995; Dehairs et al., 2000; this study), several authors have recently questioned the importance of mangrove-derived carbon to estuarine or nearshore aquatic secondary production based on mass-balance considerations. Wafar et al. (1997) estimated that the total potential C-flux of mangroves in a western Indian estuary was only $37 \%$ of the measured average phytoplankton $\mathrm{C}$ production, and this number dropped to $3-4 \%$ in terms of $\mathrm{N}$ and $\mathrm{P}$. Similarly, $\mathrm{Li}$ and Lee (1998) estimated mangrove carbon to contribute only $1 \cdot 8 \%$ to the total available carbon pool in Deep Bay, China. Using the litter fall measurements made by Dehairs et al. (2000) (weighted average of $1.2 \mathrm{~g} \mathrm{C} / \mathrm{m}^{2} /$ day) and phytoplankton primary production rates (from $1 \cdot 1$ to $3 \cdot 3 \mathrm{~g} \mathrm{C} / \mathrm{m}^{2} /$ day when assuming a depth of $1.5 \mathrm{~m}$ with photosynthetic activity, AV Raman, unpublished data), it becomes clear that the potential contribution of mangrove carbon to the system is much less than that from phytoplankton (by a factor of $\sim 5$ ), considering the relative surface areas of aquatic and mangrove habitats. It should be stressed that this is a very rough estimate which did not take into account e.g. the fact that part of the litter fall will be stored, consumed, and respired in the intertidal areas, and that a major part of the mangrove C-flux might be in the form of DOC (see Lee, 1995) or be directed towards the Bay of Bengal on the eastern edge of the forest. It also does not include potential contributions from benthic microalgae and 
from other terrestrial sources (e.g. via the Kakinada Canal, and from the Gautami Godavari), and thus no doubt overestimates the potential contribution made by mangrove litterfall.

\section{Acknowledgements}

Financial support was granted by the EC project 'Assessment of mangrove degradation and resilience in the Indian sub-continent' (contract ERB IC18CT98-0295). We are grateful to E. Keppens for granting access to the IRMS facilities, and to G. Poppe who identified some of the molluscs. Dr C. Kalavati kindly provided data on microalgal abundance in the mangrove creeks and Bay waters. We are grateful to D. P. Gillikin and two referees for their constructive suggestions to improve the manuscript.

\section{References}

Adams, T. S. \& Sterner, R. W. 2000 The effect of dietary nitrogen content on trophic level ${ }^{15} \mathrm{~N}$ enrichment. Limnology and Oceanography 45, 601-607.

Altabet, M. A. \& Francois, R. 1994 Sedimentary nitrogen isotopic ratio as a recorder for surface ocean nitrate utilization. Global Biogeochemical Cycles 8, 103-116.

Bouillon, S., Chandra Mohan, P., Sreenivas, N. \& Dehairs, F. 2000 Sources of suspended matter and selective feeding by zooplankton in an estuarine mangrove ecosystem, as traced by stable isotopes. Marine Ecology Progress Series 208, 79-92.

Bouillon, S. \& Dehairs, F. (2000) Estimating spatial and seasonal phytoplankton $\delta^{13} \mathrm{C}$ variations in an estuarine mangrove ecosystem. Isotopes in Environmental and Health Studies 36, 273-284.

Bouillon, S., Koedam, N., Raman, A. V. \& Dehairs, F. 2001 Primary producers sustaining macro-invertebrate communities in intertidal mangrove forests. Oecologia, in press (doi:10.1007/s. 0044.201.0014).

Bunn, S. E., Loneragan, N. R. \& Kempster, M. A. 1995 Effects of acid washing samples on stable isotope ratios of $\mathrm{C}$ and $\mathrm{N}$ in penaeid shrimps and seagrass: implications for food web studies using stable isotopes. Limnology and Oceanography 40, 622-625.

Canuel, E. A., Cloern, J. E., Ringelberg, D. B., Guckert, J. B. \& Rau, G. H. 1995 Molecular and isotopic tracers used to examine sources of organic matter and its incorporation into the food webs of San Fransisco Bay. Limnology and Oceanography 40, 67-81.

Cifuentes, L. A., Sharp, J. H. \& Fogel, M. L. 1988 Stable carbon and nitrogen isotope biogeochemistry in the Delaware estuary. Limnology and Oceanography 33, 1102-1115.

Coplen, T. B. $1996 \mathrm{New}$ guidelines for reporting stable hydrogen, carbon, and oxygen isotope-ratio data. Geochimica et Cosmochimica Acta 60, 3359-3360.

Daniel, P. A. \& Robertson, A. I. 1990 Epibenthos of mangrove waterways and open embayments: community structure and the relationship between exported mangrove detritus and epifaunal standing stocks. Estuarine, Coastal and Shelf Science 31, 599-619.

Dauby, P. 1990 The stable carbon isotope ratios in benthic food webs of the Gulf of Calvi, Corsica. Continental Shelf Research 9, 181-195.

Dehairs, F., Rao, R. G., Chandra Mohan, P., Raman, V., Marguillier, S. \& Hellings, L. 2000 Tracing mangrove carbon in suspended matter and aquatic fauna of the Gautami-Godavari Delta, Bay of Bengal (India). Hydrobiologia 431, 225-241.

Fleming, M., Lin, G. \& Sternberg, L. da S. L. 1990 Influence of mangrove detritus in an estuarine ecosystem. Bulletin of Marine Science 47, 663-669.
France, R. L. 1995 Carbon-13 enrichment in benthic compared to planktonic algae: foodweb implications. Marine Ecology Progress Series 124, 307-312.

Fry, B. 1983 Fish and shrimp migrations in the Norhtern Gulf of Mexico analyzed using stable C, N, and S isotope ratios. Fishery Bulletin 81, 789-801.

Fry, B. 1999 Using stable isotopes to monitor watershed influences on aquatic trophodynamics. Canadian Fournal of Fisheries and Aquatic Sciences 56, 2167-2171.

Goering, J., Alexander, V. \& Haubenstock, N. 1990 Seasonal variability of stable carbon and nitrogen isotope ratios of organisms in a north pacific bay. Estuarine, Coastal and Shelf Science 30, 239-260.

Gupta, L. P., Subramanian, V. \& Ittekot, V. 1997 Biogeochemistry of particulate organic matter transported by the Godavari River, India. Biogeochemistry 38, 103-128.

Heaton, T. H. E. 1986 Isotopic studies of nitrogen pollution in the hydrosphere and atmosphere: a review. Chemical Geology 59, 87-102.

Hellings, L., Dehairs, F., Tackx, M., Keppens, E. \& Baeyens, W. 1999 Origin and fate of organic carbon in the freshwater part of the Scheldt Estuary as traced by stable carbon isotopic composition. Biogeochemistry 47, 167-186.

Lee, S. Y. 1995 Mangrove outwelling: a review. Hydrobiologia 295, 203-212.

Lee, S. Y. 1999a Tropical mangrove ecology: physical and biotic factors influencing ecosystem structure and function. Australian Fournal of Ecology 24, 355-366.

Lee, S. Y. $1999 b$ The effect of mangrove leaf litter enrichment on macrobenthic colonization of defaunated sandy substrates. Estuarine, Coastal and Shelf Science 49, 703-712.

Lepoint, G., Nyssen, F., Gobert, S., Dauby, P. \& Bouquegneau, J.-M. 2000 Relative impact of seagrass beds and its adjacent epilithic algal community in consumer diets. Marine Biology 136, 513-518.

Li, M. S. \& Lee, S. Y. 1998 The particulate organic matter dynamics of Pearl Bay, eastern Pearl River estuary, China. I. Implications for waterfowl conservation. Marine Ecology Progress Series 172, 73-87.

Loneragan, N. R., Bunn, S. E. \& Kellaway, D. M. 1997 Are mangroves and seagrasses sources of organic carbon for penaeid prawns in a tropical Australian estuary? A multiple stable-isotope study. Marine Biology 130, 289-300.

Macko, S. A. \& Ostrom, N. E. 1994 Pollution studies using stable isotopes. In Stable isotopes in ecology and environmental science (Lajtha, K. \& Michener, R. H., eds). Blackwell Scientific Publications, $316 \mathrm{pp}$.

Marguillier, S., van der Velde, G., Dehairs, F., Hemminga, M. A. \& Rajagopal, S. 1997 Trophic relationships in an interlinked mangrove-seagrass ecosystem as traced by $\delta^{13} \mathrm{C}$ and $\delta^{15} \mathrm{~N}$. Marine Ecology Progress Series 151, 115-121.

Mariotti, A. 1983 Atmospheric nitrogen is a reliable standard for natural ${ }^{15} \mathrm{~N}$ abundance measurements. Nature 303, 685-687.

Mariotti, A., Lancelot, C. \& Billen, G. 1984 Natural isotopic composition as a tracer of origin for suspended matter in the Scheldt estuary. Geochimica et Cosmochimica Acta 48, 549555 .

McClelland, J. W., Valiela, I. \& Michener, R. H. 1997 Nitrogenstable isotope signatures in estuarine food webs: a record of increasing urbanization in coastal watersheds. Limnology and Oceanography 42, 930-937.

McClelland, J. W. \& Valiela, I. 1998 Linking nitrogen in estuarine producers to land-derived sources. Limnology and Oceanography 43, 577-585.

McKinney, R. A., Lake, J. L., Allen, M. \& Ryba, S. 1999 Spatial variability in Mussels used to assess base level nitrogen isotope ratio in freshwater ecosystems. Hydrobiologia 412, 17-24.

Middelburg, J. J. \& Nieuwenhuize, J. 1998 Carbon and nitrogen isotopes in suspended matter and sediments from the Schelde Estuary. Marine Chemistry 60, 217-225. 
Minagawa, W. \& Wada, E. 1984 Stepwise enrichment of ${ }^{15} \mathrm{~N}$ along food chains: further evidence and the relation between $\delta^{15} \mathrm{~N}$ and animal age. Geochimica et Cosmochimica Acta 48, 11351140 .

Newell, R. I. E., Marshall, N., Sasekumar, A. \& Chong, V. C. 1995 Relative importance of benthic microalgae, phytoplankton, and mangroves as sources of nutrition for penaeid prawns and other coastal invertebrates from Malaysia. Marine Biology 123, 595606.

Nieuwenhuize, J., Maas, Y. E. M. \& Middelburg, J. J. 1994 Rapid analysis of organic carbon and nitrogen in particulate materials. Marine Chemistry 45, 217-224.

Odum, W. E. \& Heald, E. J. 1975 The detritus-based food web of an estuarine mangrove community. In Estuarine Research (Cronin, L. E., ed.). Academic Press, New York, pp. 265286

Owens, N. J. P. 1987 Natural variations in ${ }^{15} \mathrm{~N}$ in the marine environment. Advances in Marine Biology 24, 389-451.

Pinnegar, J. K. \& Polunin, N. V. C. 1999 Differential fractionation of $\delta^{13} \mathrm{C}$ and $\delta^{15} \mathrm{~N}$ among fish tissues: implications for the study of trophic interactions. Functional Ecology 13, 225-231.

Ponsard, S. \& Averbuch, P. 1999 Should growing and adult animals fed on the same diet show different $\delta^{15} \mathrm{~N}$ values? Rapid Communications in Mass Spectrometry 13, 1305-1310.

Riera, P., Stal, L. J., Nieuwenhuize, J., Richard, P., Blanchard, G. \& Gentil, F. 1999 Determination of food sources for benthic invertebrates in a salt marsh (Aiguillon Bay, France) by carbon and nitrogen stable isotopes: importance of locally produced sources. Marine Ecology Progress Series 187, 301-307.

Riera, P., Montagna, P. A., Kalke, R. D. \& Richard, P. 2000 Utilization of estuarine organic matter during growth and migration by juvenile brown shrimp Penaeus aztecus in a South Texas estuary. Marine Ecology Progress Series 199, 205-216.

Risk, M. J. \& Erdmann, M. V. 2000 Isotopic composition of nitrogen in stomatopod (Crustacea) tissues as an indicator of human sewage impacts on Indonesian coral reefs. Marine Pollution Bulletin 40, 50-58.

Robertson, A. I., Alongi, D. M. \& Boto, K. G. 1992 Food chains and carbon fluxes. In Tropical mangrove ecosystems (Robertson, A. I. \& Alongi, D. M., eds). Coastal and estuarine studies no. 41. American Geophysical Union, 329 pp.

Rodelli, M. R., Gearing, J. N., Gearing, P. J., Marshall, N. \& Sasekumar, A. 1984 Stable isotope ratios as a tracer of mangrove carbon in Malaysian ecosystems. Oecologia 61, 326-333.

Rogers, K. M. 1999 Effects of sewage contamination on macroalgae and shellfish at Moa Point, New Zealand using stable carbon and nitrogen isotopes. New Zealand Fournal of Marine and Freshwater Research 33, 181-188.

Sweeney, R. E. \& Kaplan, I. R. 1980 Natural abundance of ${ }^{15} \mathrm{~N}$ as a source indicator for near-shore marine sedimentary and dissolved nitrogen. Marine Chemistry 9, 81-94.

Thornton, S. F. \& McManus, J. 1994 Application of organic carbon and nitrogen stable isotope and $\mathrm{C} / \mathrm{N}$ ratios as source indicators of organic matter provenance in estuarine systems: evidence from the Tay Estuary, Scotland. Estuarine, Coastal and Shelf Science 38, 219-233.

Tucker, J., Sheats, N., Giblin, A. E., Hopkinson, C. S. \& Montoya, J. P. 1999 Using stable isotopes to trace sewage-derived material through Boston Harbor and Massachusetts Bay. Marine Environmental Research 48, 353-375.

Wafar, S., Untawale, A. G. \& Wafar, M. 1997 Litter fall and energy flux in a mangrove ecosystem. Estuarine, Coastal and Shelf Science 44, 111-124.

Yoshii, K. 1999 Stable isotope analyses of benthic organisms in Lake Baikal. Hydrobiologia 411, 145-149.

Zieman, J. C., Macko, S. A. \& Mills, L. 1984 Role of seagrasses and mangroves in estuarine food webs: temporal and spatial changes in stable isotope composition and amino acid content during decomposition. Bulletin of Marine Science 35, 380-392.

APPENDix I. Carbon and nitrogen stable isotope ratios $\left(\delta^{13} \mathrm{C}, \delta^{15} \mathrm{~N}\right.$, expressed in\%o) of benthic invertebrates collected in the Coringa-Kakinada Bay complex, during pre-monsoon season in 1997 (indicated by ${ }^{\star}$ ) and 1999

\begin{tabular}{|c|c|c|c|c|}
\hline Location & Species & $\delta^{13} \mathrm{C}$ & $\delta^{15} \mathrm{~N}$ & $\mathrm{n}$ \\
\hline \multirow[t]{2}{*}{ Ma 1} & Diopatra neapolitana & $-23 \cdot 8$ & $+10 \cdot 4$ & 1 \\
\hline & Meretrix meretrix & $-23 \cdot 6,-23 \cdot 3$ & $+8 \cdot 1,+10 \cdot 4$ & 2 \\
\hline \multirow[t]{4}{*}{ Ma 2} & Diopatra neapolitana & $-23 \cdot 9$ & $+9 \cdot 5$ & 1 \\
\hline & Macrophthalmus sp. & $-22 \cdot 4$ & $+5 \cdot 1$ & 1 \\
\hline & Typhlocarcinus sp. & $-23 \cdot 8$ & $+4 \cdot 7$ & 1 \\
\hline & Tellina sp. 1 & $-23 \cdot 8 \pm 0 \cdot 7$ & $+6 \cdot 2 \pm 0 \cdot 8$ & 5 \\
\hline \multirow[t]{3}{*}{ Mo 1} & Tellina sp. 1 & $-21 \cdot 1$ & $+7 \cdot 6$ & 1 \\
\hline & Typhlocarcinus sp. & $-22 \cdot 4 \pm 0 \cdot 7$ & $+6 \cdot 7 \pm 0 \cdot 3$ & 5 \\
\hline & Cerithidea cingulata & $-21 \cdot 1,-20 \cdot 5$ & $+10 \cdot 8,+10 \cdot 2$ & 2 \\
\hline \multirow[t]{5}{*}{ Mo 2} & Diopatra neapolitana ${ }^{\star}$ & $-21 \cdot 2$ & $+9 \cdot 0$ & 1 \\
\hline & Dorippe facchino & $-21 \cdot 7 \pm 1 \cdot 5$ & $+6 \cdot 4 \pm 0 \cdot 5$ & 4 \\
\hline & Macrophthalmus sp. & $-22 \cdot 2,-21 \cdot 9$ & $+4 \cdot 7,+5 \cdot 2$ & 2 \\
\hline & Macrobrachium rosenbergii & $-21 \cdot 5,-20 \cdot 9$ & $+10 \cdot 3,+10 \cdot 6$ & 2 \\
\hline & Metapenaeus dobsoni & $-20 \cdot 3$ & $+9 \cdot 4$ & 1 \\
\hline \multirow[t]{3}{*}{ Mo 3} & Typhlocarcinus sp. ${ }^{\star}$ & $-20 \cdot 0$ & $+6 \cdot 9$ & 1 \\
\hline & Anadara granosa ${ }^{\star}$ & $-21 \cdot 6$ & $+8 \cdot 0$ & 1 \\
\hline & Macoma sp. ${ }^{\star}$ & $-21 \cdot 6$ & $+8 \cdot 5$ & 1 \\
\hline \multirow[t]{4}{*}{ Mo 4} & Cerithidea cingulata & $-21 \cdot 2-19 \cdot 7$ & $+9 \cdot 1,+8 \cdot 4$ & 2 \\
\hline & Dorippe facchino & $-21 \cdot 3,-20 \cdot 8$ & $+8 \cdot 9,+6 \cdot 9$ & 2 \\
\hline & Penaeus merguiensis & $-21 \cdot 1 \pm 0 \cdot 6$ & $+9 \cdot 5 \pm 1 \cdot 1$ & 3 \\
\hline & Tellina sp. 1 & $-22 \cdot 1 \pm 0 \cdot 2$ & $+8 \cdot 0 \pm 0 \cdot 4$ & 6 \\
\hline Mo 5 & Placuna placenta & $-20 \cdot 5,-20 \cdot 2$ & $+8 \cdot 7,+9 \cdot 1$ & 2 \\
\hline
\end{tabular}


912 S. Bouillon et al.

Appendix I. Continued

\begin{tabular}{|c|c|c|c|c|}
\hline Location & Species & $\delta^{13} \mathrm{C}$ & $\delta^{15} \mathrm{~N}$ & $\mathrm{n}$ \\
\hline \multirow[t]{6}{*}{$\mathrm{SEb} 1$} & Paphia undulata & $-18 \cdot 0$ & $+8 \cdot 5$ & 1 \\
\hline & Placuna placenta & $-19 \cdot 6,-19 \cdot 2$ & $+9 \cdot 5,+9 \cdot 3$ & 2 \\
\hline & Echiuroides (unid.) & $-17 \cdot 8$ & $+11 \cdot 8$ & 1 \\
\hline & Thais lacera & $-17 \cdot 9$ & $+11 \cdot 0$ & 1 \\
\hline & Metapenaeopsis stridulans & $-17 \cdot 9,-18 \cdot 2$ & $+10 \cdot 8,+4 \cdot 8$ & 2 \\
\hline & Metapenaeus brevicornis & $-18 \cdot 5$ & $+10 \cdot 8$ & 1 \\
\hline \multirow[t]{7}{*}{$\mathrm{SEb} 2$} & Paphia undulata & $-18 \cdot 5$ & $+7 \cdot 7$ & 1 \\
\hline & Tellina sp. 1 & $-18 \cdot 8 \pm 0 \cdot 4$ & $+8 \cdot 4 \pm 0 \cdot 2$ & 4 \\
\hline & Tellina sp. 2 & $-18 \cdot 4$ & $+9 \cdot 3$ & 1 \\
\hline & Diplodonta sp. & $-20 \cdot 2$ & $+8 \cdot 0$ & 1 \\
\hline & Macrophthalmus sp. & $-16 \cdot 2$ & $+6 \cdot 5$ & 1 \\
\hline & Echiuroides (unid.) & $-19 \cdot 0$ & $+12 \cdot 0$ & 1 \\
\hline & Metapenaeus brevicornis & $-18 \cdot 2$ & $+11 \cdot 8$ & 1 \\
\hline \multirow[t]{9}{*}{$\mathrm{SEb} 3$} & Meretrix meretrix & $-19 \cdot 6$ & $+9 \cdot 5$ & 1 \\
\hline & Tellina sp. 1 & $-18 \cdot 3$ & $+8 \cdot 4$ & 1 \\
\hline & Lingula sp. & $-20 \cdot 1$ & $+9 \cdot 3$ & 1 \\
\hline & Anadara granosa & $-19 \cdot 3,-19 \cdot 2$ & $+7 \cdot 2,+6 \cdot 1$ & 2 \\
\hline & Acaudina molpaidioides & $-18 \cdot 5$ & $+9 \cdot 6$ & 1 \\
\hline & Diopatra neapolitana & $-19 \cdot 4$ & $+11 \cdot 2$ & 1 \\
\hline & Oratosquilla sp. & $-18 \cdot 1$ & $+11 \cdot 4$ & 1 \\
\hline & Volema cochlidium & $-18 \cdot 0$ & $+9 \cdot 6$ & 1 \\
\hline & Penaeus merguiensis & $-19 \cdot 2$ & $+9 \cdot 3$ & 1 \\
\hline \multirow[t]{9}{*}{$\mathrm{CNb} 1$} & Paphia undulata & $-18 \cdot 7$ & $+12 \cdot 9$ & 1 \\
\hline & Leucosia sp. & $-18 \cdot 0$ & $+11 \cdot 4$ & 1 \\
\hline & Dorippe facchino & $-16 \cdot 7$ & $+10 \cdot 7$ & 1 \\
\hline & Nassarius olivaceus & $-17 \cdot 5$ & $+11 \cdot 9$ & 1 \\
\hline & Portunus sanguinolentus & $-16 \cdot 8$ & $+12 \cdot 9$ & 1 \\
\hline & Harpiosquilla sp. & $-17 \cdot 6$ & $+7 \cdot 8$ & 1 \\
\hline & Metapenaeopsis sp. & $-15 \cdot 9$ & $+13 \cdot 4$ & 1 \\
\hline & Metapenaeus monoceros & $-22 \cdot 7,-16 \cdot 1$ & $+14 \cdot 5,+11 \cdot 9$ & 2 \\
\hline & Charybdis sp. & $-17 \cdot 0,-16 \cdot 2$ & $+11 \cdot 4,+11 \cdot 7$ & 2 \\
\hline \multirow[t]{4}{*}{$\mathrm{CNb} 2$} & Paphia undulata & $-17 \cdot 5$ & $+12 \cdot 0$ & 1 \\
\hline & Pinctada radiata & $-17 \cdot 4$ & $+11 \cdot 6$ & 1 \\
\hline & Macrophthalmus sp. & $-17 \cdot 9,-17 \cdot 3$ & $+9 \cdot 5,+8 \cdot 0$ & 2 \\
\hline & Typhlocarcinus sp. & $-14 \cdot 6 \pm 1 \cdot 9$ & $+9 \cdot 8 \pm 1 \cdot 5$ & 3 \\
\hline \multirow[t]{4}{*}{$\mathrm{CNb} 3$} & Paphia undulata & $-17 \cdot 2$ & $+8 \cdot 1$ & 1 \\
\hline & Nassarius sp. ${ }^{\star}$ & $-15 \cdot 3$ & $+10 \cdot 5$ & 1 \\
\hline & Murex trapa $a^{\star}$ & $-16 \cdot 0$ & $+9 \cdot 9$ & 1 \\
\hline & Typhlocarcinus sp. ${ }^{\star}$ & $-17 \cdot 3$ & $+7 \cdot 2$ & 1 \\
\hline \multirow[t]{2}{*}{$\mathrm{CNb} 4$} & Meretrix meretrix & $-16 \cdot 0 \pm 0 \cdot 3$ & $+9 \cdot 8 \pm 0 \cdot 8$ & 4 \\
\hline & Tellina sp. 2 & $-16 \cdot 4 \pm 0 \cdot 5$ & $+6 \cdot 8 \pm 1 \cdot 6$ & 6 \\
\hline \multirow[t]{7}{*}{$\mathrm{CNb} 5$} & Paphia undulata & $-18 \cdot 0,-16 \cdot 9$ & $+11 \cdot 1$, n.d. & 2 \\
\hline & Anadara granosa & $-17 \cdot 3,-16 \cdot 8$ & $+10 \cdot 0,+10 \cdot 4$ & 2 \\
\hline & Charybdis sp. & $-17 \cdot 1$ & $+13 \cdot 4$ & 1 \\
\hline & Macrophthalmus sp. & $-16 \cdot 7,-15 \cdot 5$ & $+7 \cdot 5,+5 \cdot 9$ & 2 \\
\hline & Murex trapa & $-14 \cdot 5,-14 \cdot 4$ & $+13 \cdot 9,+13 \cdot 9$ & 2 \\
\hline & Nassarius olivaceus & $-17 \cdot 1,-16 \cdot 9$ & $+13 \cdot 2,+12 \cdot 0$ & 2 \\
\hline & Typhlocarcinus sp. & $-15 \cdot 5 \pm 0.9$ & $+10 \cdot 7 \pm 0.5$ & 3 \\
\hline \multirow[t]{4}{*}{$\mathrm{CNb} 6$} & Paphia undulata & $-16 \cdot 6$ & $+9 \cdot 4$ & 1 \\
\hline & Anadara natalensis ${ }^{\star}$ & $-16 \cdot 6$ & $+8 \cdot 3$ & 1 \\
\hline & Babylonia canaliculata ${ }^{\star}$ & $-15 \cdot 6$ & $+12 \cdot 2$ & 1 \\
\hline & Typhlocarcinus sp.` & $-17 \cdot 0$ & $+8 \cdot 9$ & 1 \\
\hline \multirow[t]{2}{*}{$\mathrm{CNb} 7$} & Penaeus merguiensis & $-21 \cdot 5$ & $+7 \cdot 3$ & 1 \\
\hline & Parapenaeopsis stylifera & $-15 \cdot 1$ & $+12 \cdot 6$ & 1 \\
\hline \multirow[t]{5}{*}{$\mathrm{CNb} 8$} & Paphia undulata ${ }^{\star}$ & $-16 \cdot 4$ & $+8 \cdot 9$ & 1 \\
\hline & Typhlocarcinus sp. ${ }^{\star}$ & $-15 \cdot 9$ & $+8 \cdot 3$ & 1 \\
\hline & Murex trapa $a^{\star}$ & $-15 \cdot 4$ & $+10 \cdot 9$ & 1 \\
\hline & Anadara granosa ${ }^{\star}$ & $-17 \cdot 1$ & $+10 \cdot 2$ & 1 \\
\hline & Meretrix meretrix ${ }^{\star}$ & $-18 \cdot 2$ & $+12 \cdot 0$ & 1 \\
\hline
\end{tabular}


Stable isotope analysis of benthic invertebrates from a mangrove estuary 913

Appendix I. Continued

\begin{tabular}{|c|c|c|c|c|}
\hline Location & Species & $\delta^{13} \mathrm{C}$ & $\delta^{15} \mathrm{~N}$ & $\mathrm{n}$ \\
\hline \multirow[t]{2}{*}{ CNb 8} & Nassarius sp. ${ }^{\star}$ & $-17 \cdot 4$ & $+11 \cdot 1$ & 1 \\
\hline & Philyra sp. ${ }^{\star}$ & $-16 \cdot 8$ & $+8 \cdot 3$ & 1 \\
\hline \multirow{2}{*}{$\mathrm{CNb} 9$} & Paphia undulata & $-17 \cdot 7$ & $+9 \cdot 9$ & 1 \\
\hline & Tetilla dactyoloidea & $-18 \cdot 4$ & $+12 \cdot 1$ & 1 \\
\hline \multirow[t]{6}{*}{$\mathrm{CNb} 10$} & Paphia undulata & $-16 \cdot 7$ & $+9 \cdot 6$ & 1 \\
\hline & Typhlocarcinus sp. ${ }^{\star}$ & $-18 \cdot 9$ & $+10 \cdot 1$ & 1 \\
\hline & Murex trapa $a^{\star}$ & $-15 \cdot 7$ & $+11 \cdot 3$ & 1 \\
\hline & Nassarius olivaceus ${ }^{\star}$ & $-17 \cdot 0$ & $+11 \cdot 5$ & 1 \\
\hline & Nasssarius sp.` & $-15 \cdot 1$ & $+10 \cdot 9$ & 1 \\
\hline & Charybdis sp. * & $-16 \cdot 5,-16 \cdot 1$ & $+9 \cdot 6,+9 \cdot 4$ & 2 \\
\hline \multirow[t]{5}{*}{$\mathrm{CNb} 11$} & Charybdis sp. & $-15 \cdot 7$ & $+13 \cdot 0$ & 1 \\
\hline & Harpiosquilla sp. & $-16 \cdot 2$ & $+11 \cdot 9$ & 1 \\
\hline & Murex trapa & $-16 \cdot 7$ & $+11 \cdot 9$ & 1 \\
\hline & Tellina sp. 2 & $-16 \cdot 9$ & $+8 \cdot 0$ & 1 \\
\hline & Penaeus semisulcatus & $-13 \cdot 8$ & $+10 \cdot 6$ & 1 \\
\hline \multirow[t]{7}{*}{$\mathrm{CNb} 12$} & Paphia undulata ${ }^{\star}$ & $-16 \cdot 9$ & $+8 \cdot 7$ & 1 \\
\hline & Typhlocarcinus sp. ${ }^{\star}$ & $-19 \cdot 2$ & $+8 \cdot 4$ & 1 \\
\hline & Nassarius olivaceus $\star$ & $-18 \cdot 7$ & $+10 \cdot 9$ & 1 \\
\hline & Thais lacera ${ }^{\star}$ & $-14 \cdot 9$ & $+9 \cdot 0$ & 1 \\
\hline & Macoma sp.* & $-17 \cdot 1$ & $+8 \cdot 9$ & 1 \\
\hline & Siliqua albida ${ }^{\star}$ & $-16 \cdot 5$ & $+7 \cdot 6$ & 1 \\
\hline & Harpiosquilla sp.* & $-16 \cdot 1$ & $+10 \cdot 3$ & 1 \\
\hline
\end{tabular}

